\title{
The Use of ICT in Learning English: A Study of Students in Moroccan Universities
}

\author{
Habiba Hafa, Mohammed Moubtassime
}

\author{
Faculty of Arts and Human Sciences Dhar El Mehraz, Sidi Mohamed Ben Abdellah University, Morocco
}

\begin{abstract}
This study aims at investigating Moroccan university students' access to ICT tools and internet connection, their frequency and purposes of ICT use and their perceived benefits of ICT use in learning English. The data have been obtained by means of a quantitative study. Research findings indicated that access to ICT tools is still limited among the respondents. Access to internet connection within the respondents' universities was also found to be inadequate. Furthermore, the study revealed that the respondents' use of ICT for educational purposes is limited. On the other hand, students' perceptions towards the benefits of ICT use in learning English were found to be highly positive. The findings of this study were discussed and compared to the findings of other related studies.
\end{abstract}

Keywords - ICT, Access, Learning English, frequency and purposes of use, Perceptions.

\section{Introduction}

Language pedagogy and language learning have been influenced to a great extent by the development of ICT [23].

Thus, the use of ICT in teaching and learning process has become a topic of interest to many researchers and educators, particularly in the

\section{DOI: $10.18421 /$ SAR41-04 \\ https://doi.org/10.18421/SAR41-04}

Corresponding author: Habiba Hafa,

Faculty of Arts and Human Sciences Dhar El Mehraz, Sidi Mohamed Ben Abdellah University, Morocco.

Email: habibahafa1@gmail.com

Received: 28 February 2021.

Revised: 16 March 2021.

Accepted: 20 March 2021.

Published: 22 March 2021.

(cc)BY-NC-ND (C) 2021 Habiba Hafa \& Mohammed Moubtassime; published by UIKTEN. This work is licensed under the Creative Commons AttributionNonCommercial-NoDerivs 3.0 License.

The article is published with Open Access at www.sarjournal.com language classroom. Morocco, like all the countries in the world, has started to recognize the importance of integrating ICT into teaching and learning process. The policy adopted by the ministry of National Education shows that the country aims at introducing different reforms; among which is the use of ICT in education. This was clear from the implementation of the National Charter for Education and Training in 1999 [17]. The latter focused on the use of ICT in education in general and more particularly in the language classroom, and it has paved the way to launching a number of projects that aimed at spreading the use of ICT in education. The most important of these projects is the Moroccan National Research and Education Network (MARWAN) that was launched in 1998. The main goal behind the creation of MARWAN was to interconnect the different Moroccan higher education and research institutions through allowing them to have access to the internet [18].

The use of ICT in learning process is thought to be of great importance especially for university students [20]. The use of ICT helps to transform this process from being highly teacher-dominated to a more student-centered one. This transformation will automatically increase the learning gain for students as well as the opportunity to develop their creativity, problem solving abilities and communication skills [3].

However, data to support the role and the way ICT could be used to enhance the learning of English in Moroccan universities are still limited [19]. Similarly, students' perceptions of the benefits associated with ICT use in learning the English language have been rarely studied. On the other hand, the government is giving too much importance to investing more money on ICT projects and initiatives in Moroccan universities.

This study focuses on the use of ICT in learning English among Moroccan university students. The study relies on the assumption that ICT can be used by students to facilitate the learning of English. Thus, the specific objectives of this study are to explore the degree of access to ICT tools, internet connection, the frequency and the way ICT is used for both educational and non-educational purposes among 
Moroccan university students. The study also aims at investigating the respondents' perceptions of the benefits associated with ICT use in English language learning.

It is hoped that the findings of the present study will provide important information about the use of ICT in Moroccan universities and therefore allow the ministry of higher education to take the necessary measures to initiate and encourage the use of ICT in learning the English language.

The study aims at answering the following questions:

1. What kind of ICT tools are Moroccan university students of English able to access?

2. How often do they use ICT for educational purposes and how often do they use it for noneducational purposes?

3. In what way do they use ICT for educational and non-educational purposes?

4. What are their perceptions of the benefits associated with the use of ICT in learning English?

\section{Literature Review}

\section{a. Definition}

ICT stands for Information and Communication Technology, the term is defined differently in the literature since it is considered as an umbrella term.

UNESCO [27] defined ICT as forms of technology used for creating, displaying, storing and exchanging information. Similarly, Jager and Lokman [8] stated that ICT is a generic term referring to technologies. These technologies can be used for different functions such as collecting, storing, editing and passing on information in various forms. A more technical definition was suggested by UNESCO [26] which suggested that the definition of ICT requires the definition of two other terms which are informatics (Computing Science) and informatics technology. Informatics was defined as the science dealing with information processing systems in terms of the design, realization, evaluation, use and maintenance. These information-processing systems include hardware, software, organizational and human aspects. Informatics Technology was defined as the technological applications of informatics in society.

In her definition of ICT, Lloyd [15] suggested that the acronym ICT stands for Information and Communication Technology or alternatively Information and Communications Technology; thus, the author focused on the word "communication" whether it is singular or plural. The importance of the differing number of the word, according to the author, springs from the fact that the singular form has to do with human interaction; whereas, the plural form is concerned with the whole field of data communication infrastructure. Therefore, the singular form of the word "communication" is the process or the outcome, while the plural form is about the technology itself.

The same thing can be said about the word "technology", which is included in the acronym. The word can also take the plural form "technologies" referring to the specific devices, tools or processes which make up the "technology". To be more specific, ICT in this study refers to technological devices such as smartphones, tablets, desktops, laptops, the internet, in addition to electronic delivery systems, among others, that are widely used in today's education [6].

\section{ICT usage in Teaching and Learning Foreign Languages}

In recent years, a lot of interest is given to the use of ICT in education, and the way it can be used in order to improve the efficiency and effectiveness of teaching and learning process. In this respect, Bilyalova [3] conducted a study with the purpose of evaluating the importance of ICT usage in teaching foreign languages in universities. The author stated that each teacher applying ICT on foreign language lessons should be aware of the fact that any educational technology should meet the following methodological requirements: conceptuality, consistency, efficiency, flexibility, dynamics and reproduction. The results of the study concluded that the most effective types of ICT for the development of linguistic and communication competence of students are the following: PowerPoint presentation, correspondence by email, training programs on CDROM and internet resources.

Similarly, Lim and Tay [14] stated that ICT tools are very essential in achieving the objectives of the lesson. For the authors, the classification of an ICT tool is based more on how it is used than its characteristics. According to the authors, ICT tools can be divided into four categories mainly, informative tools, situating tools, communicative tools and constructive tools. Informative tools are applications that give the teachers and the students a large amount of information in different formats. Communicative tools are those devices that give teachers and students the opportunity to communicate with each other even if they are not in the classroom. Situating tools are those tools that put students in an environment which involves a context, and the occurrence of a situation. Constructive tools are those tools that can be used for different teaching and learning purposes such as manipulating 
information, constructing one's own knowledge or visualizing one's understanding [14].

Similarly, Erben et al. [5] suggested another categorization of ICT tools that could be used in English language classrooms. The first type of ICT tools is referred to as E-creation tools. This type of ICT tools enables students to use the language to create, explore and discover while producing content and learning performances. The second type of ICT tools is E-communication tools. What is meant here is software that enables teachers and students to communicate with each other. The third type of ICT tools is reading/writing facilitative E-tools. Examples of these tools include online boards, online journals, blogs, wikis and E-books. The fourth type of ICT tools is referred to as listening/speaking facilitative tools. This type of ICT tools enables learners to develop their listening skills through the use of a number of ICT tools such as audio and video files, audio and video sharing libraries like YouTube, etc. The last type of ICT tools is E-assessment tools. With this type, the learners can produce performances, projects or portfolios that can be used later with other pieces of learning evidence to demonstrate achievement.

A more or less similar categorization of ICT tools was suggested by Luo and Lei [16], the authors stated that ICT tools could be divided into four types:

- Educational networking: it refers to online learning platforms that rely on social networking technologies such as Facebook and WhatsApp to connect learners.

- Web-based learning: it refers to online services or applications such as social bookmarking, podcasting and virtual worlds. The latter could be used by learners to perform different tasks such as receiving, organizing and generating learning materials.

- Mobile learning: it refers to mobile devices or technologies that could be used for learning purposes such as smartphones.

- Classroom equipment: it refers to stand-alone devices used in traditional classrooms such as interactive whiteboards and touch-screen computers.

\section{a. Impact of ICT on learning the English language}

A considerable amount of literature has highlighted the benefits of ICT use for learning purposes. According to Jager and Lokman [8], ICT has different functions in education. Firstly, it is used as an assisting tool, especially when making assignments, collecting data, communicating and making research. Secondly, ICT is a medium of teaching and learning, the medium through which teachers can teach and learners can learn. This appears in many different forms, such as drill and practice exercises. Finally, the authors stated that ICT is a tool for organization and management in schools.

$\mathrm{Fu}[6]$ argued that the use of ICT has been found to assist students in accessing digital information efficiently and effectively, since it is used by students to discover learning topics, solve problems and provide solutions to the problems they may face during the learning process. Jung [10] mentioned other benefits that are associated with the use of ICT in learning English, such as offering more opportunities to develop critical thinking skills, improving the teaching and learning quality and supporting teaching and learning by facilitating access to course content.

With the use of ICT, students are also exposed to authentic learning activities and new problemsolving methods. Language becomes more of a reality when using different telecommunications such as emails and chats. Therefore, students have the chance to practice the learning process in real world settings. They are also engaged in a process of active learning, because they design and produce their own knowledge representations [9].

\section{Methodology}

\section{a. Instrumentation}

The main instrument used in this study is the questionnaire. The latter is divided into four main sections with a total of 51 items which are closeended items. The questionnaire was designed and modified from Jung [10] and Tri and Nguyen [24]. The first section was devoted to elicit background information about the participants. Section 2 had to do with students ICT accessibility and connectivity. Section 3 was meant to investigate students' frequency of ICT use and ways in which different technological tools are used for educational and noneducational purposes. The last section aimed at exploring students' perceived benefits of ICT use in learning English using a total of 9 items in the closed-ended format on a five point Likert Scale (Strongly disagree, disagree, neutral, agree and strongly agree).

\section{b. Participants}

The respondents included in this study are university students of English selected from two Moroccan universities. Mainly, the university of Sidi Mohamed Ben Abdellah, Dhar-El Mehraz, Fez and the university of Moulay Ismail, Faculty of Arts and Humanities, Meknes. The respondents were selected randomly. Indeed, 290 is the number of respondents who participated in this investigation: 175 respondents from the faculty of $\mathrm{Fez}$ and 115 
respondents from the faculty of Meknes during the academic year 2019-2020.

Before administering the questionnaire, it seemed necessary to pilot it first. In this respect the researcher distributed 14 copies to students, and after they filled out the questionnaire, they were asked to provide the researcher with any comments or suggestions concerning the level of difficulty and clarity of the items. Thus, the piloting stage helped ensure that the items included in the questionnaire were accessible in terms of content as well as length.

The data has been collected over a period of three weeks, the researcher distributed a total of 306 copies of the questionnaire and was able to recover 290 responses which represents a return rate of $94,7 \%$. Of the participants, $44 \%$ were males and $56 \%$ were females. The average age of the participants was 21 years old. $38 \%$ of the respondents were first year students, $33 \%$ of them were second year students and $29 \%$ of them were third year students.

\section{c. Data analysis}

In the present study, the Statistical Package for Social Sciences (SPSS) was used to perform statistical analysis. Thus, the quantitative data obtained through the use of the questionnaire were analyzed numerically and presented through the use of statistics, tables and graphs.

\section{Results}

\section{a. Access to ICT tools and internet connection}

Table 1. The respondents access to ICT tools

\begin{tabular}{|l|c|c|}
\hline \multirow{2}{*}{\multicolumn{1}{|c|}{ Materials }} & \multicolumn{2}{c|}{ Response Rate } \\
\cline { 2 - 3 } & Frequency & Percentage \\
\hline Smartphone & 280 & 96,6 \\
\hline Laptop & 140 & 48,3 \\
\hline Tablet & 30 & 10,3 \\
\hline Desktop computer & 70 & 24,1 \\
\hline Printer & 40 & 13,8 \\
\hline Scanner & 20 & 6,9 \\
\hline 3G/4G cellular modem & 90 & 31 \\
\hline ADSL modem & 83 & 28,6 \\
\hline Cellular phone & 15 & 5,2 \\
\hline $\begin{array}{l}\text { USB flash drive or } \\
\text { external hard drive }\end{array}$ & 200 & 69 \\
\hline
\end{tabular}

The first question was asked to explore the respondents' access to ICT tools. The results in Table 1 indicates that a great majority of the respondents have smartphones $(96,6 \%)$ and USB flash drives or external hard drives $(69 \%), 48,3 \%$ of the respondents own a laptop, $24,1 \%$ have a desktop computer,
$28,6 \%$ have an ADSL modem and $31 \%$ have a $3 \mathrm{G} / 4 \mathrm{G}$ cellular modem.

A very small portion of the respondents have the following equipment: printers $(13,8 \%)$, tablets $(10,3 \%)$, scanners $(6,9 \%)$ and cellular phones $(5,2 \%)$.

Table 2. The respondents access to internet connection

\begin{tabular}{|l|c|c|}
\hline & Frequency & Percentage \\
\hline At home & 270 & 93,1 \\
\hline At the university & 71 & 24,5 \\
\hline $\begin{array}{l}\text { At public places (Coffee } \\
\text { shops, libraries, etc.) }\end{array}$ & 226 & 77,9 \\
\hline
\end{tabular}

Concerning the respondents access to internet connection, Table 2 indicates that almost the majority of the respondents $(93,1 \%)$ have access to the internet at home and $77,9 \%$ of the respondents have access to the internet at public places; whereas, only $24,5 \%$ of them stated that they could access the internet at their universities.

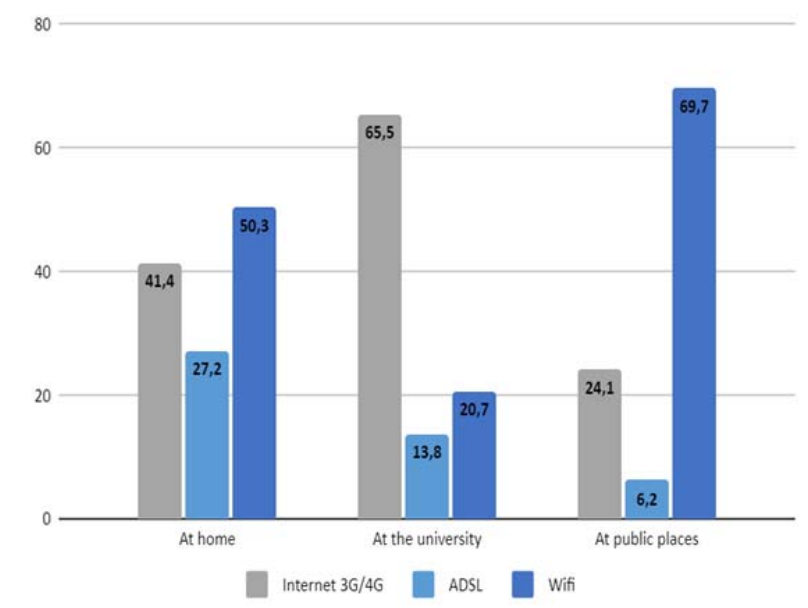

Figure 1. The respondents' internet connection mode

As far as the respondents' mode of internet connection is concerned, the results show that $19 \%$ of the respondents get connected to the internet at home through using more than one mode of internet connection. $41,4 \%$ of the respondents get connected to the internet using $3 \mathrm{G} / 4 \mathrm{G}$ connection, and $50,3 \%$ of them rely on WiFi to connect to the internet. However, a limited number of the respondents uses ADSL as a mode of internet connection at home $(27,2 \%)$.

As regards public places (coffee shops, libraries, etc.), the results show that $69,7 \%$ of the respondents connect to the internet through WiFi, $24,1 \%$ of them connect to the internet relying on $3 \mathrm{G} / 4 \mathrm{G}$ connection and $6,2 \%$ of them use ADSL as a mode of internet connection at public places.

However, when it comes to the respondents mode of internet connection at their universities, the results 
indicate that $65,5 \%$ of them connect to the internet via $3 \mathrm{G} / 4 \mathrm{G}$ connection and only $20,7 \%$ connect through Wifi, while $13,8 \%$ of the respondents connect through ADSL.

\section{b. Frequency and purposes of ICT use}

Table 3. The respondents' frequency of ICT use for educational purposes

\begin{tabular}{|l|c|c|}
\hline & Frequency & Percentage \\
\hline Daily & 18 & 6,2 \\
\hline Twice a week & 73 & 25,2 \\
\hline Once a Week & 169 & 58,3 \\
\hline Once a month & 21 & 7,2 \\
\hline Never & 9 & 3,1 \\
\hline
\end{tabular}

As far as the frequency of ICT use for educational purposes is concerned, Table 3 indicates that the majority of the respondents $(58,3 \%)$ use ICT once a week, while $25,2 \%$ of them use ICT twice a week and $9,3 \%$ of them use it once a month. Surprisingly enough, the lowest score was attributed to "daily" with a rate of $6,2 \%$. Lastly, $3,1 \%$ of the participants reported that they never use ICT in learning English language.

The findings related to this part of the questionnaire revealed that ICT is not frequently used for educational purposes on the part of the respondents.

Table 4. The respondents' frequency of ICT use for noneducational purposes

\begin{tabular}{|l|c|c|}
\hline & Frequency & Percentage \\
\hline Daily & 253 & 87,2 \\
\hline Twice a week & 19 & 6,6 \\
\hline Once a Week & 12 & 4,1 \\
\hline Once a month & 6 & 2,1 \\
\hline Never & 0 & 0 \\
\hline
\end{tabular}

As indicated in Table 4 almost the majority of the respondents $(87,2 \%)$ reported that they use ICT on a daily basis and $6,6 \%$ of them use ICT twice a week. Only $4,1 \%$ of the respondents reported a response of "once a week" and 2,1\% reported that they use ICT once a month. Interestingly, however, no one of the respondents reported that he or she never uses ICT, which means that all the respondents use ICT for non-educational purposes, though the frequency of use may differ from one respondent to another.

As far as the respondents use of ICT for educational purposes, it is notable from the table below (Table 5) that the highest rated activities are using online dictionaries with a percentage rate of $95,5 \%$ and using the internet for translation with a percentage rate of $83,8 \%$; followed by using
YouTube videos to improve listening skills, preparing for exams and using online resources to do vocabulary and grammar exercises with a percentage rate of $82,1 \%, 80,3 \%$ and $74,5 \%$ respectively.

The results also show that $70,3 \%$ of the respondents use ICT to prepare for oral activities, $67,9 \%$ of them use it for writing and reading practices. Additionally $53,4 \%$ of the respondents reported that they use ICT to access e-library materials and $49 \%$ of them use it to discuss learning issues with classmates.

On the other side, the results of the frequency analysis show that the lowest response rates belong to the following activities: downloading websites for learning English (37,6\%), downloading mobile applications that could be used for learning purposes $(38,3 \%)$ and using ICT to discuss learning issues with teachers $(40,3 \%)$.

Table 5. The respondents' use of ICT for educational purposes

\begin{tabular}{|l|c|c|}
\hline \multicolumn{1}{|c|}{ Activity } & Frequency & Percentage \\
\hline $\begin{array}{l}\text { downloading websites for } \\
\text { learning English }\end{array}$ & 109 & 37,6 \\
\hline $\begin{array}{l}\text { downloading mobile } \\
\text { applications to facilitate the } \\
\text { learning tasks (e.g. Google } \\
\text { Drive) }\end{array}$ & 111 & 38,3 \\
\hline Using online dictionaries. & 277 & 95,5 \\
\hline $\begin{array}{l}\text { Using the internet for } \\
\text { translation. }\end{array}$ & 243 & 83,8 \\
\hline Preparing for oral activities. & 204 & 70,3 \\
\hline $\begin{array}{l}\text { Using YouTube videos to } \\
\text { improve listening skills. }\end{array}$ & 238 & 82,1 \\
\hline $\begin{array}{l}\text { Using online resources for } \\
\text { writing and reading } \\
\text { practices. }\end{array}$ & 197 & 67,9 \\
\hline $\begin{array}{l}\text { Using online resources to do } \\
\text { vocabulary and grammar } \\
\text { exercises. }\end{array}$ & 216 & 74,5 \\
\hline $\begin{array}{l}\text { Using e-library materials } \\
\text { (books, articles, magazines). }\end{array}$ & 155 & 53,4 \\
\hline Preparing for exams. & 233 & 80,3 \\
\hline $\begin{array}{l}\text { Using ICT to discuss } \\
\text { learning issues with } \\
\text { classmates. }\end{array}$ & 142 & 49,3 \\
\hline $\begin{array}{l}\text { Using ICT to discuss } \\
\text { learning issues with teachers. }\end{array}$ & 17 & \\
\hline
\end{tabular}

Concerning the non-educational activities that the respondents frequently engage in, the results indicated in Table 6 show that the massive majority of the respondents $(93,1 \%)$ use ICT to participate in social networking (Facebook, WhatsApp, etc.) and $79,3 \%$ of them use ICT to watch online videos (e.g. YouTube), followed by corresponding through 
emails and blogs $(76,6 \%)$, using chat rooms and discussion groups $(69,3 \%)$ and listening to music $(65,9 \%)$. Besides, $48,3 \%$ of the respondents use ICT to play online games, $37,9 \%$ of the them reported using ICT to read e-magazines and newspapers, and $24,1 \%$ of them use ICT to read about their hobbies. On the other hand, the lowest response rates belong to the following activities: using satellite and mapping applications (10,3\%), online banking $(9,3 \%)$, online shopping $(8,6 \%)$ and looking for holidays and concert tickets $(6,9 \%)$.

Table 6. The respondents' use of ICT for non-educational purposes

\begin{tabular}{|l|c|c|}
\hline \multicolumn{1}{|c|}{ Activity } & Frequency & Percentage \\
\hline $\begin{array}{l}\text { Corresponding through emails } \\
\text { and blogs }\end{array}$ & 222 & 76,6 \\
\hline Reading about your hobbies & 70 & 24,1 \\
\hline $\begin{array}{l}\text { Using chat rooms/ discussion } \\
\text { groups }\end{array}$ & 201 & 69,3 \\
\hline Listening to music & 191 & 65,9 \\
\hline $\begin{array}{l}\text { Watching online videos } \\
\text { (e.g. YouTube...) }\end{array}$ & 230 & 79,3 \\
\hline Online shopping & 25 & 8,6 \\
\hline $\begin{array}{l}\text { Reading e-magazines and } \\
\text { newspapers }\end{array}$ & 110 & 37,9 \\
\hline $\begin{array}{l}\text { Using social networking sites } \\
\text { (Facebook, WhatsApp, etc.) }\end{array}$ & 270 & 93,1 \\
\hline Playing online games & 140 & 48,3 \\
\hline $\begin{array}{l}\text { Using satellite and mapping } \\
\text { applications }\end{array}$ & 30 & 10,3 \\
\hline Online banking & 27 & 9,3 \\
\hline $\begin{array}{l}\text { Looking for holidays and } \\
\text { concert tickets }\end{array}$ & 20 & 6,9 \\
\hline
\end{tabular}

The results of this study revealed that the respondents' use of ICT for non-educational purposes is at a higher frequency compared to their use of ICT for educational purposes; mainly, the respondents use ICT for participating in social networking, entertainment and communication.

This may be justified by the evolution of social media and instant messaging, offering a lot of advantages to users. Through using computers, tablets and smartphones, people can go online accessing social networks and entertainment websites anytime and anywhere.

\section{c. Perceived benefits of ICT use in teaching English}

The results obtained concerning the respondents' perceived benefits of ICT use in learning English language are presented in the Table below (Table 7).
Table 7. The respondents perceptions of the benefits of ICT use in English learning (SD: strongly disagree, D: disagree, $N$ : neutral, A: agree, SA: strongly agree)

\begin{tabular}{|l|c|c|c|c|c|}
\hline \multicolumn{1}{|c|}{ Statement } & SD & D & N & A & SA \\
\hline $\begin{array}{l}\text { The use of ICT makes } \\
\text { the learning of English } \\
\text { easier, more enjoyable } \\
\text { and effective. }\end{array}$ & 0,6 & 1,6 & 9,5 & 67,1 & 21,2 \\
\hline $\begin{array}{l}\text { ICT motivates me to } \\
\text { learn English. }\end{array}$ & 1,2 & 4,4 & 9,2 & 52,5 & 32,7 \\
\hline $\begin{array}{l}\text { Learning English } \\
\text { through the use of ICT } \\
\text { saves time, effort and } \\
\text { money. }\end{array}$ & 0,8 & 4 & 11,6 & 40,2 & 43,4 \\
\hline $\begin{array}{l}\text { The use of ICT helps me } \\
\text { improve my reading and } \\
\text { writing skills. }\end{array}$ & 2,2 & 3,4 & 14,1 & 57,1 & 23,2 \\
\hline $\begin{array}{l}\text { The use of ICT helps me } \\
\text { improve my listening } \\
\text { and speaking skills. }\end{array}$ & 1,7 & 3,1 & 14,3 & 47,7 & 33,2 \\
\hline $\begin{array}{l}\text { The use of ICT helps me } \\
\text { avoid problems such as } \\
\text { lack of vocabulary, } \\
\text { difficulties in } \\
\text { pronunciation and } \\
\text { grammar issues. }\end{array}$ & 2,2 & 4,1 & 15,2 & 61,3 & 17,2 \\
\hline $\begin{array}{l}\text { ICT allows me to have } \\
\text { easy access to a huge } \\
\text { source of updated } \\
\text { English learning } \\
\text { materials. }\end{array}$ & 4,1 & 7,2 & 14,2 & 55,4 & 19,1 \\
\hline $\begin{array}{l}\text { The use of ICT in } \\
\text { learning English is more } \\
\text { effective than using } \\
\text { books and other printed } \\
\text { materials. }\end{array}$ & 5,3 & 7,1 & 18,4 & 55,7 & 13,5 \\
\hline $\begin{array}{l}\text { ICT helps me } \\
\text { communicate with my } \\
\text { teachers about teaching } \\
\text { and learning issues. }\end{array}$ & 7,3 & 20,5 & 10,5 & 34,4 & 27,3 \\
\hline
\end{tabular}

The results show that most of the respondents hold positive perceptions of the impact of ICT use on learning English language. 88,3\%, 85,2\% and 83,6\% of the respondents respectively agree and strongly agree that the use of ICT makes learning of English easier, more enjoyable and effective, motivates them to learn English and allows them to save more time, effort and money.

Additionally, $80,3 \%$ of the respondents strongly agree that the use of ICT helps them improve their English reading and writing skills and $80,9 \%$ of them agree and strongly agree that the use of ICT helps them improve their listening and speaking skills. A large number of the respondents $(78,5 \%)$ concurred that the use of ICT in learning English helps them avoid problems such as lack of vocabulary, difficulties in pronunciation and grammar issues. 
Lastly, $74,5 \%, 69,2 \%$ and $61,7 \%$ of the respondents respectively agree that the use of ICT in learning English language allows them to have access to a huge source of updated English learning materials, is more effective than using books and other printed materials and that ICT helps them communicate with their teachers about teaching and learning issues.

These results clearly indicate that the massive majority of the respondents hold positive perceptions of the impact of ICT use on learning English language. Thus, there is no disagreement among the respondents concerning the benefits associated with the use of ICT in the learning of English.

\section{Article Analysis}

\section{a. Students access to ICT tools and internet connection}

In the present study, the respondents were surveyed to explore their access to ICT tools and their connectivity to the internet. The results indicated that the majority of the respondents $(96,6 \%)$ have access to smartphones, and USB flash drives or USB hard drives (69\%); Whereas, almost half of the respondents reported that they have a laptop and about quarter of them have a desktop computer.

Tablets, cell phones, scanners, printers, ADSL modems and $3 \mathrm{G} / 4 \mathrm{G}$ cellular modems recorded the lowest.

These findings support the research findings by Oulmaati et al. [20] that there is inequality in terms of computer and modem ownership among Moroccan university students. It is worth noting, though, that the government is making great efforts to generalize the use of ICT in all public schools and universities and enable Moroccan students to have access to ICT tools. Examples of such initiatives are the programs INJAZ and LAWHATI. The former aimed at enabling $\mathrm{PhD}$ and master students to benefit from a package comprising a laptop and high-speed internet service subscriptions. The latter program aimed at making 'tablets 2 in 1' available to all students of higher education institutions [13].

The implication here is that the government should double the efforts to make technology accessible to all students.

As far as access to internet connection is concerned, the majority of the respondents who participated in this study stated that they could have access to the internet at home using different modes of internet connection. However, the most frequently used mode of internet connection is $\mathrm{WiFi}$ and $3 \mathrm{G} / 4 \mathrm{G}$. Actually, this finding goes in line with the main objectives of the government's "Maroc Digital" strategy. The latter aimed at enabling the whole population to have access to fixed or mobile broadband access by 2022 [28].

Similarly, a great majority of the respondents stated that they could have access to the internet in public places and that they mainly access the internet in these places via WiFi which is now available in the majority of public places. This is due to the liberalization and privatization policy adopted by the country in the sector of telecommunications. This in turn has led to more access to the internet at a very low cost [7].

Interestingly enough, only $24 \%$ of the respondents reported that they could have access to the internet at their universities.

The analysis of the descriptive data further revealed that $3 \mathrm{G} / 4 \mathrm{G}$ is the most frequently used mode of internet connection at their respective universities and only $20,7 \%$ of the respondents connect to the internet via $\mathrm{WiFi}$ at their universities. This means that these universities do not provide adequate internet facilities to students and that students rely on private internet services if they want to access the internet inside their universities. Apuke and Iyendo [2] came up with a similar finding in their study which revealed that about $86,8 \%$ of the respondents do not have adequate access to internet facilities on their campus.

This clearly indicates that special attention should be paid to the issue of internet access inside Moroccan universities. Besides, decision makers and university leaders should provide students with the necessary resources to ensure the effectiveness of the learning process.

\section{b. Frequency and purposes of ICT use}

In terms of ICT frequency of use, the present study revealed that the majority of students $(87,2 \%)$ uses ICT on a daily basis for non-educational purposes.

Only $6,2 \%$ of the respondents use ICT daily for educational purposes, whereas the majority of them use it once or twice a week.

This finding goes in line with the study by Jung [10] which revealed that the majority of the respondents spent more time using ICT for nonlearning purposes (more than ten hours per week). Similar results were also found by Tri and Nguyen [24] whose study aimed at examining students' use of ICT in terms of frequency and purposes. The results of the study indicated that the majority of the respondents $(88,4 \%)$ spent more time using ICT for general purposes (communication and entertainment) rather than using it for learning purposes. The results of the study by Buabeng-Andoh and Issifu [4] did also reveal that the students' pedagogical use of ICT was very low and that the respondents used ICT to communicate with peers more than other types of ICT application. Similarly, the main non-educational 
activities that the respondents in the present study practice frequently is the use of social networking sites, corresponding through emails and blogs and watching YouTube videos. As far as the use of ICT for educational purposes is concerned, the data obtained revealed that the most frequent activities that the respondents get involved in are using online dictionaries, using the internet for translation, using online videos to improve listening skills and vocabulary and preparing for exams.

However, it is worth noting that a very limited number of the respondents reported that they use ICT to download websites for learning English, though the majority of them own smartphones which could be used for this purpose. The data also revealed that the majority of the respondents do not use ICT to download mobile applications that could be used to facilitate the learning tasks. The example that was given to the respondents is Google Drive. This application, for instance, allows its users to safely store and access their documents, spreadsheets, presentations, etc., from anywhere freely. On the other hand, the results of the study showed that the majority of the respondents own USB flash drives or USB hard drives, which have almost the same function of the previously mentioned application.

What can be inferred from this finding is that the majority of the respondents lack knowledge of some useful websites for learning English that could be downloaded on their smartphones. Similarly, the respondents are not aware of some of the latest web applications that could be used to help students facilitate the learning tasks.

The present research study did also reveal that $59,7 \%$ of students do not use ICT to discuss learning issues with their teachers. This implies that online interaction between teachers and students is very limited. Thus, the students do not benefit from the wide range of advantages associated with online interaction and involvement while learning English language [21]. Actually, the finding of the present study aligns with the findings of another research study that investigated students' use of ICT in the learning process [20].

\section{c. Students perceptions of the benefits associated with ICT use in learning English}

The data revealed that the respondents involved in this study hold positive perceptions of the benefits associated with ICT use in the process of English learning. Therefore, no disagreement was shown in this respect.

It is principally concluded that the use of ICT in learning English motivates students and helps them obtain information in an easier, more enjoyable and effective way. This finding is consistent with the finding of Jung's [10] study which revealed that the respondents who were university students of English, demonstrated a great tendency to study English through the use of ICT. The respondents viewed these tools as being entertaining, enjoyable, useful and motivating. Similar results were also obtained by the study of Wiyaka, Mujiyanto and Rukmini [29].

Furthermore, the respondents in the present study did not disagree with the fact that ICT allows them to have access to a huge source of knowledge and information, and that it is a means of deepening their understanding of different aspects of the English language. This result resonates with the results of the studies by Tristiana and Rosyida [25]. The respondents involved in this study indicated that the use of ICT helps them gain more information on different subjects. Thus, the overall degree of university students' perceptions towards using ICT in learning English in this study was high as well.

Similar to the findings of Zinan and Sai's [30] study, the respondents in the present study agreed that learning English through the use of ICT is more effective than learning through the use of books and other printed materials. This finding was supported by other research findings which associated the use of ICT in learning English with different advantages, compared to a traditional learning environment which is characterized by face-to-face interaction with the teacher and the use of limited printed materials [1].

Additionally, it is clear from the data obtained that the respondents hold positive perceptions concerning the impact of ICT on their learning; specifically, in relation to saving time, energy and money.

Actually, a similar finding was reported by Khan, Bhakti and Khan [11] who stated that the use of ICT allows students to have access to updated learning materials. The latter help them accomplish their tasks and improve their learning. This in turn leads to saving more time, effort and money.

Furthermore, the findings of the present study revealed that $78,5 \%$ of the respondents agreed and strongly agreed that the use of ICT can help them avoid problems such as lack of vocabulary, difficulties in pronunciation and grammar issues. This finding supports the finding by Silviyanti [22] that the use of ICT, particularly watching videos on YouTube, has been found to be very beneficial for students. Through watching such videos, students are given the opportunity to pronounce the words like native speakers and also acquire new vocabulary.

As far as students perceived benefits of ICT use in improving the learning of the four language skills, the results of the present study revealed that listening and speaking are the two skills that scored the highest in terms of agreement, followed by reading and writing. These findings go in line with what has been claimed by many researchers that the use of ICT gives students great opportunities to develop language skills. ICT provides students with a variety of video and audio materials; therefore, they are allowed to practice different listening and speaking activities in a more extensive way [12]. ICT tools are 
also very essential to develop a deeper understanding of the other skills [10].

However, it is worth noting that a limited number of the respondents agreed that ICT helps them communicate with their teachers about teaching and learning matters. The implication here is that the role of ICT in facilitating communication between the students and their teachers is still neglected. The importance of online interaction between the teacher and the students has been highlighted by many researchers. For instance, Zinan and Sai [30] argued that teachers should participate in their students online activities so that they could facilitate the learning of English language. Examples of such activities include forums and chat rooms. Thus, awareness should be raised among university teachers concerning the role of online interaction between teachers and students in teaching and learning process.

\section{Conclusion and Recommendations}

Based on the results obtained from the present study, which aimed at investigating the degree of access to ICT tools and internet connection, the frequency and purposes of ICT use and the perceived benefits of ICT use in English language learning among Moroccan university students, several conclusions could be drawn.

First, the study revealed that students' accessibility to ICT tools such as laptops, desktops and iPads is still limited, except that the majority of the respondents own smartphones. As far as connectivity to the internet is concerned, it was found that the massive majority of the respondents have access to the internet at home and that $3 \mathrm{G} / 4 \mathrm{G}$ and $\mathrm{WiFi}$ are the most frequently used modes of internet connection by the respondents. The study also revealed that the respondents' accessibility to internet connection in their universities is very limited.

Second, it was found that the majority of the respondents involved in this study spend more time using ICT for non-educational purposes such as using social networking sites, corresponding through emails and blogs and watching videos on YouTube. Thus, the respondents spend less time using ICT for educational purposes. Using online dictionaries, using the internet for translation and preparing for exams were among the most frequently practiced activities by the respondents.

Third, students' perceptions of the benefits of using ICT in learning English were found to be positive. Thus, another conclusion that could be drawn from this investigation is that university students are aware of the importance of ICT use in learning English. The use of ICT resources motivates them since it allows them to get more learning materials in an easy, effective and enjoyable way. Therefore, students could learn different aspects of the English language through having access to a huge source of updated English learning materials.
Accordingly, ICT is perceived as a means that allows the respondents to save time, effort and money. They also think that the use of ICT makes learning English more effective than learning with the use of books and other printed materials. Besides, the use of ICT helps students develop the four skills (listening, speaking, reading and writing) in addition to overcoming some difficulties in pronunciation, vocabulary and grammar. Generally speaking, the respondents have shown positive perceptions of ICT use in learning English language. However, when it comes to the role of ICT in helping students communicate with their teachers, a very limited proportion of the respondents agreed that ICT helps them interact with their teachers outside the university.

\section{Some recommendations are the following:}

- The government should double its efforts through launching more ICT projects and initiatives with the aim to make ICT accessible to all Moroccan students.

- The Ministry of Higher Education should take the necessary measures to initiate and encourage the use of ICT in learning foreign languages in Moroccan universities.

- Moroccan universities should provide students with the necessary internet connection facilities. This will help create an ICT-based environment that contributes in facilitating the learning of English language.

- Workshops that aim at raising students' awareness to the importance of exploiting the potential of ICT to serve educational purposes should be organized.

- Training on the use of the latest ICT applications as well as on the use of ICT tools and resources in the context of language learning should be given to all students to achieve the desired learning outcomes.

- Teachers' awareness towards the importance of online interaction with their students should be raised.

\section{References}

[1]. Adesoji, F. (2011). Undergraduate students perception of the effectiveness of ICT use in improving teaching and learning in Ekiti State University, Ado-Ekiti, Nigeria. International Journal of Library and Information Science, 4(7), 121-130.

[2]. Apuke, O. D., \& Iyendo, T. O. (2018). University students' usage of the internet resources for research and learning: forms of access and perceptions of utility. Heliyon, 4(12), e01052.

[3]. Bilyalova, A. (2017). ICT in teaching a foreign language in high school. Procedia-Social and Behavioral Sciences, 237, 175-181. 
[4]. Buabeng-Andoh, C., \& Issifu, Y. (2015). Implementation of ICT in learning: A study of students in Ghanaian secondary schools. Procediasocial and behavioral sciences, 191, 1282-1287.

[5]. Erben, T., Ban, R., \& Castaneda, M. (2008). Teaching English language learners through technology. Routledge.

[6]. Fu, J. (2013). Complexity of ICT in education: A critical literature review and its implications. International Journal of education and Development using ICT, 9(1), 112-125.

[7]. Hamdy, A. (2007). Survey of ICT and education in Africa: Morocco country report (English). InfoDev ICT and Education Series Washington, D.C.: World Bank Group.

[8]. Jager, A. K., \& Lokman, A. H. (2000). The Impact of ICT in Education: The Role of the Teacher and Teacher Training. Stoas Research.

[9]. Jayanthi, N. S., \& Kumar, R. V. (2016). Use of ICT in English language teaching and learning. Journal of English Language Teaching and Learning, 3(2), 3438.

[10]. Jung, S. H. (2006). The use of ICT in learning English as an international language (Doctoral dissertation).

[11]. Khan, S. A., Bhatti, R., \& Khan, A. A. (2011). Use of ICT by Students: A Survey of Faculty of Education at IUB. Library Philosophy and Practice, 1.

[12]. Kiliçkaya, F. (2018). Information and communications technology (ICT) in listening instruction. The TESOL Encyclopedia of English Language Teaching, 1-7.

[13]. Laayouni, L. (2016). Les TIC dans l'enseignement supérieur au Maroc vers la plate forme numérique nationale. Open Education Day in Marrakech, Morocco.

[14]. Lim, C. P., \& Tay, L. Y. (2003). Information and communication technologies (ICT) in an elementary school: Students' engagement in higher order thinking. Journal of Educational Multimedia and Hypermedia, 12(4), 425-451.

[15]. Lloyd, M. (2006). Towards a definition of the integration of ICT in the classroom. AARE'05 Education Research Creative Dissent: Constructive, $1-18$.

[16]. Luo, H., \& Lei, J. (2012). Emerging technologies for interactive learning in the ICT age. In Educational stages and interactive learning: From kindergarten to workplace training (pp. 73-91). IGI Global.
[17]. MEN (1999). The national charter for education and training. Retrieved from: https://www.men.gov.ma. [accessed: 25 December 2020].

[18]. Merrouch, R. (2018). MARWAN moroccan NREN. e-AGE18 - Amman 2-3 December.

[19]. Naciri, H. (2015). Using ICT to improve higher education in Morocco. In Conference Proceedings. ICT for Language Learning (Vol. 467).

[20]. Oulmaati, K., Ezzahri, S., \& Samadi, K. (2017). The Use of ICT in the learning process among the students of History and Civilization at Abdelmalek Essaadi University, Morocco. International Journal of Scientific Research \& Engineering Technology (IJSET), 8(2), 972-979.

[21]. Raman, A., \& Mohamed, A. H. (2013). Issues of ICT Usage among Malaysian Secondary School English Teachers. English Language Teaching, 6(9), 74-82.

[22]. Silviyanti, T. M. (2014). Looking into EFL students' perceptions in listening by using English movie videos on YouTube. Studies in English language and Education, 1(1), 42-58.

[23]. Tanveer, M. (2011). Integrating e-learning in classroom-based language teaching: Perceptions, challenges and strategies. In International Conference “ICT for Language Learning” (pp. 23-28).

[24]. Tri, D. H., \& Nguyen, N. H. T. (2014). An exploratory study of ICT use in English language learning among EFL university students. Teaching English with Technology, 14(4), 32-46.

[25]. Tristiana, N. E., \& Rosyida, E. (2018). Students' Perception on the Integrating of Information and Communication Technology (ICT). English Education: Jurnal Tadris Bahasa Inggris, 11(1), 3544.

[26]. Unesco. (2002). Information and communication technology in education: a curriculum for schools and programme of teacher development. Unesco.

[27]. UNESCO (2006). The United Nations Educational, Scientific and Cultural organization (UNESCO), using ICT to develop literacy.

[28]. UNESCO (2017). Stratégie Maroc digital 2020, le ministère de l'industrie, de l'investissement, du commerce et de l'économie numérique.

[29]. Wiyaka, W., Mujiyanto, J., \& Rukmini, D. (2018). Students perception on the usefulness of ICT-based language program. English Language Teaching, 11(2), 53-60.

[30]. Zinan, W., \& Sai, G. T. B. (2017). Students' Perceptions of Their ICT-Based College English Course in China: A Case Study. Teaching English with Technology, 17(3), 53-76. 